\title{
BIOPOLÍTICA E RACISMO DE ESTADO: UMA LEITURA do CURSO EM DEFESA DA SOCIEDADE (1975-1976) DE MICHEL FOUCAULT
}

\author{
[Biopolitics AND Racism of State: AN ANALysis of Michel FouCAUlt's IN DEFENSE OF \\ SOCIETY (1975-1976)]
}

\author{
Fernando Danner * \\ Universidade Federal de Rondônia, Brasil
}

\begin{abstract}
RESUMO: O artigo inicia com uma investigação sobre a relação entre política e guerra e, em seguida, apresenta a genealogia foucaultiana da luta das raças; por fím, discute a questão do racismo de Estado, associado ao tema da pureza e da proteção da raça, no âmbito das sociedades ocidentais modernas.
\end{abstract}

Palavras-Chave: Guerra; Política; Soberania; Luta das raças; Racismo de Estado
ABSTRACT: The paper begins with an investigation on the relation between politics and war and, next, it presents the Foucault's genealogy of the racial struggle; from here, it discusses the matter of racism of State associated to the ideas or racial purity and racial protection, in the sphere of modern Western societies.

KEYWORDS: War; Politics; Sovereignty; Struggle of races; Racism of State

\section{INTRODUÇÃO}

este artigo, analiso a questão do racismo de Estado no pensamento de
Michel Foucault. No curso Em Defesa da Sociedade, Foucault apresenta uma investigação histórica acerca da relação entre guerra e política (ou poder político). Nesse sentido, eu apresento, inicialmente, a crítica de Foucault à concepção jurídicopolítica do poder (ou poder de soberania), e demonstro que ela é incapaz de compreender as relações de poder tais como elas se desenvolvem nas sociedades modernas. A tese de Foucault é a de que, no cerne do sistema jurídico ocidental, estava a tarefa de estabelecer a legitimidade do poder do rei/soberano e, ao mesmo tempo, ele era responsável por definir os limites de exercício desse poder. Em outras palavras, para Foucault, ao mesmo tempo que buscava eliminar o "fato da dominação" implícito no poder soberano, o sistema jurídico ocidental se encarregava de mostrar tanto os direitos legítimos da soberania quanto a obrigação legal da obediência dos súditos ao poder soberano; a análise de Foucault, por sua vez, no lugar da soberania e da obediência, evidencia os procedimentos e instrumentos utilizados pela sociedade moderna para a sujeição e a dominação dos indivíduos. Num segundo momento, minha análise trata do problema principal do curso: a política é a guerra continuada por outros meios. Nesta

* Doutor em filosofia pela PUCRS. Professor do Departamento de Filosofia, do Programa de Pós-Graduação em Filosofia (PPGFIL) e do Mestrado Profissional Interdisciplinar em Direitos Humanos e Desenvolvimento da Justiça (DHJUS) da Universidade Federal de Rondônia - UNIR. E-mail:fernando.danner@gmail.com 
seção, interessa-me, sobretudo, demonstrar a tese da guerra como relação social permanente e, em seguida, apresentar como o discurso histórico-político da luta das raças, já no decorrer do século XIX, assume a forma não de uma luta entre duas raças, e sim a de uma raça, considerada como "verdadeira e única", contra os indivíduos e grupos sociais considerados perigosos ao "patrimônio biológico" da sociedade. $\mathrm{Na}$ terceira seção, ao tratar da contra-história da luta das raças, eu demonstro que, na primeira metade do século XIX, quando o discurso da luta das raças estava assumindo a forma de um discurso revolucionário, de luta de classes, ocorreu uma requalificação da contra-história da luta das raças, no âmbito dos Estados modernos: ela assume, nesse momento, um sentido essencialmente biológico e médico. Além disso, apresento o argumento de Foucault de que é precisamente quando a luta de raças se configura como princípio fundamental da "pureza da raça" que emerge o racismo. É nesse sentido que o discurso da raça, no sentido singular, no âmbito dos Estados modernos, faz amplo uso de técnicas médico-normalizadoras como instrumento de pureza e de proteção da raça. $\mathrm{Na}$ última seção, ao tratar do racismo de Estado, eu descrevo uma modificação importante no que concerne ao exercício do poder no mundo moderno. Foucault faz a genealogia do racismo em oposição direta à teoria clássica da soberania: na teoria clássica da soberania, o "direito de vida e de morte" se configurava num atributo essencial do poder/direito soberano. O "direito de vida e de morte" soberano significa, em última instância, que ele têm o direito de "fazer morrer ou de deixar viver"; já no século XIX, na ótica de Foucault, vê-se aparecer uma transformação importante no direito político ocidental, a saber: contrariamente ao direito de vida e de morte do poder soberano, o novo poder se encarrega do "direito de fazer viver e de deixar morrer". Foucault denominou esse fenômeno de "estatização do biológico", que é caracterizado por uma tecnologia de poder que se aplica à vida e aos processos biológicos da espécie humana - biopolítica. Com efeito, além de apresentar as características mais significativas dessa nova tecnologia de poder, eu descrevo brevemente as duas experiências históricas totalitárias que levaram ao extremo esse poder sobre a vida - o nazismo alemão e o socialismo soviético.

\section{A CRÍTICA À CONCEPÇ̃̃o JURÍDICO-POLÍTICA DO PODER}

No curso de 1976, intitulado Em Defesa da Sociedade, Foucault investiga a relação entre a política e a guerra. Nas onze aulas do curso, Foucault mostra como apareceu, no discurso histórico e político da modernidade, nos séculos XVII e XVIII, a tese de que a política é a guerra continuada por outros meios. Com efeito, a tese geral exposta no curso é uma inversão do princípio de Clausewitz, a saber, "a guerra não passa da política continuada" (FOUCAULT, 2005, p. 54). É nesse contexto que Foucault, em seu projeto genealógico, vai propor uma interpretação da racionalidade política moderna trazendo à tona um conjunto de saberes políticos (saberes locais, menores, descontínuos, sujeitados, silenciados, anticientíficos etc.) que haviam sido deixados às margens pelo discurso histórico, político e científico hegemônico na modernidade. Portanto, é a "liberação" desses saberes que permitirá a Foucault compreender a guerra como chave analítica de inteligibilidade do poder político, isto é, da política entendida em termos de guerra, de luta e de enfrentamento (FOUCAULT, 2005, p. 27; ADVERSE, 2014, p. 297-298).

É pela retomada desses saberes que Foucault vai poder propor uma crítica à 
concepção de poder dominante da modernidade, a saber, a "concepção jurídicodiscursiva do poder" ou do "poder de soberania". Foucault argumenta que, nas sociedades ocidentais modernas, desde a Idade Média, o pensamento jurídico esteve organizado em torno do poder régio. Isto é, a elaboração do sistema jurídico ocidental serviu como instrumento de justificação e de legitimidade do poder do rei. O sistema jurídico ocidental respeitava uma dupla tarefa: de um lado, a tarefa de justificar os direitos e o poder do rei, estabelecendo, assim, a legitimidade de seu poder; e, de outro, cabia a ele a tarefa de definir os limites do exercício desse mesmo poder soberano (absoluto) do rei. Nesse sentido, quando se diz que o sistema jurídico ocidental esteve centrado na figura do rei, quer-se significar também duas coisas: 1. a totalidade da armadura jurídica pertencente ao poder do rei e, além disso, a forma como ele se constituía no corpo vivo da soberania e como seu poder se constituía num direito fundamental; 2. os limites desse poder, isto é, era necessário determinar no interior de quais limites o soberano (rei) poderia exercer o seu poder e manter sua legitimidade (FOUCAULT, 2005, p. 30-31).

Ora, ao demonstrar que o problema da soberania é o problema central da teoria jurídica ocidental, Foucault se esforça em deixar claro que a função principal tanto do discurso quanto da técnica e da prática do direito foi a de apagar, no próprio interior do exercício do poder soberano, o "fato da dominação" e, no lugar dela, fazer aparecer tanto os "direitos legítimos da soberania" quanto a "obrigação legal da obediência". Diz ele:

O papel essencial da teoria do direito, desde a Idade Média, é o de fixar a legitimidade do poder: o problema maior, central, em torno do qual se organiza toda a teoria do direito é o problema da soberania. Dizer que o problema da soberania é o problema central do direito nas sociedades ocidentais significa que o discurso e a técnica do direito tiveram essencialmente como função dissolver, no interior do poder, o fato da dominação, para fazer que aparecessem no lugar dessa dominação, que se queria reduzir e mascarar, duas coisas: de um lado, os direitos legítimos da soberania, do outro, a obrigação legal da obediência. O sistema do direito é inteiramente centrado no rei, o que quer dizer que é, em última análise, a evicção do fato da dominação e de suas consequências (FOUCAULT, 2005, p. 31).

Para Foucault, o sistema do direito e o campo judiciário são instrumentos primordiais - e permanentes - de veiculação ao mesmo tempo de relações de dominação e de técnicas múltiplas relações de sujeição que se cristalizam em toda a estrutura social. Por isso, Foucault sugere que se analise o direito não pelo aspecto da legitimidade (da lei, da norma, do poder, da soberania etc.), mas a partir do conjunto dos procedimentos de sujeição que lhes são característicos e, por consequência, ele põe em prática. Nas próprias palavras de Foucault, trata-se de "curto-circuitar ou evitar esse problema, central para o direito, da soberania e da obediência dos indivíduos submetidos a essa soberania, e fazer que apareça, no lugar da soberania e da obediência, o problema da dominação e da sujeição" (FOUCAULT, 2005, p. 32).

Assim, ao delimitar o problema de sua análise em torno dos conceitos de "dominação" e de "sujeição", Foucault evita fazer uma análise tradicional do poder. Por "análise tradicional do poder", Foucault entende cinco coisas.

(a) ao invés de fazer uma análise do poder a partir das formas centralizadas regulamentadoras e de legitimadoras do poder, Foucault se preocupa em estudar e analisar o modo como o poder se exerce (é praticado) em suas extremidades: trata-se de 
analisar o poder, portanto, ultrapassando o limite das técnicas e procedimentos veiculadas nas regras de direito, e ver como ele se exerce em suas instituições mais regionais - até mesmo periféricas -, como, por exemplo, no fenômeno da punição. (É sabido que, ao analisar o fenômeno da punição, Foucault estava interessado em apreender o modo como o poder de punir se prolonga em um amplo e variado conjunto de instituições - locais, regionais, matérias -, de técnicas, de instrumentos e de procedimentos de sujeição, portanto, sua preocupação estava em captar as instâncias institucionais, físicas, regulamentares e até mesmo violentas dos aparelhos destinados a aplicação do direito e do poder de punir);

(b) não apreender o poder tomando como referência seu âmbito de aplicação ou de decisão, nem de estudá-lo "do lado de dentro" ou do lado da "posse" ("quem tem o poder, afinal?") ou da "intenção" ("o que tem na cabeça e o que procura aquele que tem o poder"?); é preciso apreendê-lo em sua "face externa", na sua prática real, isto é, nos seus alvos, nos seus objetos, nos seus pontos e procedimentos de fixação e, finalmente, nos próprios efeitos reais por ele produzidos - a sujeição dos corpos, dos gestos, dos comportamentos etc. Portanto, é a constituição dos súditos - e não o modo como o soberano aparece no alto e no centro do poder $^{1}-$ o objeto primordial da análise de Foucault das relações de poder na modernidade;

(c) é preciso também evitar analisar o poder na forma de um "fenômeno maciço e homogêneo de dominação" - de indivíduos, de grupos ou de classes sobre outros(as); além disso, Foucault sugere que o poder deve ser entendido não como algo que é exclusivo de um indivíduo, grupo ou classe e aqueles que não o possuem e que, por conseguinte, estão submetidos à ele; é preciso encarar o poder como algo que circula permanentemente, que funciona em uma espécie de cadeia ininterrupta de relações e, portanto, não como algo que está localizado em um local determinado ou que se encontra na posse de alguns, assumindo a ordem de uma riqueza ou bem: "o poder funciona. O poder se exerce em rede e, nessa rede, não só os indivíduos circulam, mas estão sempre em posição ser submetidos a esse poder e, também, de exercê-lo. Jamais eles são o alvo inerte ou consentidor do poder, são sempre seus intermediários. [...] o poder transita pelos indivíduos, não se aplica a eles" (FOUCAULT, 2005, p. 34-35). É nesse sentido que uma das teses mais marcantes da crítica do poder de Foucault é a tese de que os indivíduos são os efeitos imediatos e, ao mesmo tempo, os intermediários das relações de poder (FOUCAULT, 2005, p. 35; FOUCAULT, 1979, p. 182);

(d) deve-se evitar também uma análise dedutiva do poder do centro até as camadas mais baixas da sociedade; ao contrário, é preciso fazer uma "análise ascendente do poder", isto é, trata-se de partir dos mecanismos, das técnicas e táticas do poder e ver como eles "foram e ainda são investidos, colonizados, utilizados, inflectidos, transformados, deslocados, estendidos etc. por mecanismos cada vez mais gerais e por formas de dominação global" (FOUCAULT, 2005, p. 36). Portanto, não é como fenômeno global de dominação que se deve analisar o poder; ao contrário, é preciso analisar os fenômenos, as técnicas e os procedimentos de exercício de poder no âmbito de suas práticas reais e efetivos e no modo como essas práticas de se conectam a práticas mais globais de dominação;

(e) finalmente, é preciso analisar o poder a partir de sua interligação com os mecanismos de formação e de acúmulo de saber, ou seja, trata-se de estudá-lo pela ótica dos instrumentos e mecanismos de observação, de registro, de procedimentos de investigação, de pesquisa e de verificação; isto quer dizer que não se pode apreender o poder e seus efeitos de modo adequado sem compreender, conjuntamente, os 
mecanismos de formação, de organização e de acúmulo de saber que ele elabora e, por conseguinte, põe em prática novamente (FOUCAULT, 2005, p. 40).

Portanto, na perspectiva de Foucault, é preciso apreender o poder nem a partir do âmbito dos aparelhos de Estado nem a partir do conjunto das ideologias políticas que o acompanham; ao contrário, é no âmbito da dominação, das formas de sujeição, dos instrumentos e procedimentos de sujeição e nas estratégias de poder-saber que se deve orientar a análise do poder: "em suma, é preciso desvencilhar-se do modelo do Leviatã, desse modelo de um homem artificial, a um só tempo autômato, fabricado e unitário igualmente, que envolveria todos os indivíduos reais, e cujo corpo seriam os cidadãos, mas cuja alma seria a soberania. É preciso estudar o poder fora do modelo do Leviatã, fora do campo delimitado pela soberania jurídica e pela instituição do Estado; trata-se de analisá-lo a partir das técnicas e táticas de dominação (FOUCAULT, 2005, p. 40).

Até agora apresentei a tese foucaultiana de que o sistema jurídico (o sistema de direito) ocidental esteve articulado em torno do poder régio, bem como desenvolvi a tese de que o poder deve ser analisado a partir dos conceitos de "dominação" e de "sujeição". Na sequência, justifico a tese apresentada por Foucault de que a teoria da soberania não é adequada para se compreender o campo múltiplo das relações e do exercício efetivo do poder na modernidade.

Foucault apresenta três argumentos para justificar sua posição crítica de que a teoria jurídica da soberania não é adequada para justificar essa multiplicidade de relações de poder no âmbito das sociedades modernas: em primeiro lugar, Foucault afirma que a soberania esteve centrada naquilo que ele chamou de "ciclo do sujeito ao sujeito", ou seja, a soberania tenta mostrar como um sujeito, entendido enquanto um indivíduo dotado de direitos e capacidades naturais, se transforma em um indivíduo sujeitado em uma relação de poder. Portanto, a teoria da soberania se constitui em uma teoria que assume a forma de uma relação (política) do sujeito com o sujeito (do sujeito que deve ser sujeitado em uma relação de poder). Em segundo lugar, a teoria da soberania se configura em uma unidade fundamental e fundadora do poder, isto é, a multiplicidade de poderes que ela carrega só se torna efetivamente poderes, no sentido político do termo, por intermédio de uma "unidade do poder", seja ela fundamentada na forma da fisionomia do soberano, do monarca ou do próprio Estado. É dessa unidade do poder, fundamentada e fundada pela soberania, que se desenvolve, por conseguinte, todo o conjunto de mecanismos e instituições destinadas ao exercício do poder na modernidade. Em terceiro lugar, Foucault argumenta que a teoria da soberania estabelece o modo como um poder se constitui não em conformidade com a lei, mas de um princípio superior a ela, que vai inclusive permitir que todas as leis funcionem: a legitimidade do poder soberano (Cf.: FOUCAULT, 2005, p. 50).

Nesse sentido, o projeto genealógico de Foucault, no lugar de se perguntar pelas relações de soberania (manifestada na tríade sujeito-unidade-lei), procura ressaltar as "relações e os operadores de dominação". Esta reorientação lhe permite colocar em evidência as diferentes relações de poder/sujeição que fabricam esses mesmos sujeitos; além disso, ela lhe permite identificar, ao mesmo tempo, como o conjunto dos dispositivos/operadores de dominação se estruturam em uma cadeia global de estratégias de poder que se utilizam de técnicas, táticas e instituições locais de dominação e como eles se apoiam num conjunto de instrumentos técnicos cuja função é estreitar e garantir essas relações de dominação e de sujeição. É com base nisso que Foucault pode concluir que "todos os grandes aparelhos de poder" modernos se apoiam e funcionam a partir desses dispositivos de dominação (Cf.: FOUCAULT, 2005, p. 51- 
52). Diz Foucault:

Em vez da tríplice preliminar da lei, da unidade e do sujeito - que faz da soberania a fonte do poder e o fundamento das instituições -, eu acho que temos de adotar o ponto de vista tríplice das técnicas, da heterogeneidade das técnicas e de seus efeitos de sujeição, que fazem dos procedimentos de dominação a trama efetiva das relações de poder e dos grandes aparelhos de poder. A fabricação do sujeito muito mais do que a gênese do soberano [...] (FOUCAULT, 2005, p. 52).

\section{A POLÍTICA COMO GUERRA CONTINUADA POR OUTROS MEIOS}

Nesta seção, investigo o significado da tese central do curso: a política é a guerra continuada por outros meios. Foucault diz que há, nessa tese, uma espécie de paradoxo histórico. Isto é, desde a Idade Média até a época moderna, o desenvolvimento dos Estados fez com que as práticas, as instituições e os instrumentos de guerra se concentrassem cada vez mais no interior de um poder central - a esse fato histórico Foucault chamou de "estatização da guerra", ou seja, a declaração da guerra e, consequentemente, a manipulação de seus instrumentos, só podem ser feitos mediante a autorização dos poderes estatais. Como consequência dessa estatização da guerra, se apagou, gradativamente, no interior do corpo social, aquela espécie de guerra cotidiana/privada, seja ela na forma de luta de um indivíduo contra o outro, de um grupo contra o outro, de um povo contra o outro etc., que caracterizou as sociedades durante o período medieval. Portanto, a estatização das guerras, além de fazê-la existir e ser praticada exclusivamente nas fronteiras dos Estados, fez com que ela se configurase como atribuição profissional e técnica de um aparelho militar centralizado na instituição do exército (FOUCAULT, 2005, p. 55).

Para Foucault - e aqui está o paradoxo por ele percebido -, é precisamente no momento em que a guerra começa a ser exercida nos limites dos Estados que surge um tipo de "discurso novo", cuja origem remonta o fim das guerras civis e religiosas do século XVI, descrito na forma de um discurso histórico-político da guerra entendida como "relação social permanente" e como "fundamento de todas as relações e instituições de poder" (FOUCAULT, 2005, p. 56). Além disso, Foucault assinala que esse discurso se configurou, no século XVII, em instrumento privilegiado das lutas e da organização política durante a revolução burguesa inglesa e, na mesma direção, na França, também no século XVII, já no fim do reinado de Luís XIV, como instrumento contestatório pela aristocracia francesa contra a instauração da monarquia absoluta e administrativa (Cf.: FOUCAULT, 2005, p. 56-57).

Qual é o sentido novo trazido por esse discurso? Aos olhos de Foucault, no interior desses discursos, que é antagônico ao discurso filosófico-jurídico das teorias do contrato social, encontra-se a tese de que "o poder político não começa quando cessa a guerra" (FOUCAULT, 2005, p. 58). Obviamente que Foucault está ciente de que, inicialmente, o nascimento dos Estados e a organização de seu aparato jurídico-políticoadministrativo tiveram origem nas (e pelas) na guerra e nas batalhas. Parece-me, contudo, que o que está interessando Foucault, quando ele analisa o tema/discurso da "política como guerra continuada por outros meios", é muito mais desfazer aquilo que ele chama de "falsas paternidades" quando referimo-nos ao binômio poder político/guerra - isto é, a figura do Príncipe (Maquiavel) ou a da soberania absoluta (Hobbes); nesse sentido, Foucault situa o aparecimento desse discurso, no século XVII, 
na Inglaterra e na França (como acima descrevemos), e, sobretudo, discurso históricopolítico da guerra das raças. Não é meu interesse reconstruir a totalidade dos argumentos contidos na análise de Foucault em relação às noções de guerra-poder político-revolução presentes tanto no discurso dos opositores ao absolutismo monárquico na Inglaterra (Diggers e Levellers) quanto no discurso dos opositores ao Rei Luís XIV na França (especialmente na figura de Boulainvilliers); minha intenção é mostrar que Foucault procura curto-circuitar a tese contida nos teóricos da soberania por meio de uma "história das raças", ao demonstrar que a origem do poder está nas batalhas, nas vitórias, na usurpação, nos massacres etc. Diz Foucault:

[...] o direito, a paz, as leis nasceram no sangue e na lama das batalhas. [...] a lei não nasce da natureza, junto das fontes frequentadas pelos primeiros pastores; $a$ lei nasce das batalhas reais, das vitórias, dos massacres, das conquistas que têm sua data e seus heróis de horror; a lei nasce das cidades incendiadas, das terras devastadas; ela nasce com os famosos inocentes que agonizam no dia que está amanhecendo. Mas isto não quer dizer que a sociedade, a lei e o Estado sejam como que o armistício nessas guerras, ou sanção definitiva das vitórias. A lei não é pacificação, pois, sob a lei, a guerra continua a fazer estragos no interior de todos os mecanismos de poder, mesmo os mais regulares. A guerra é que é o motor das instituições e da ordem: a paz, na menor de suas engrenagens, faz surdamente a guerra. Em outras palavras, cumpre decifrar a guerra sob a paz: a guerra é a cifra mesma da paz. Portanto, estamos em guerra uns contra os outros; uma frente de batalha perpassa a sociedade inteira, contínua e permanentemente, e é essa frente de batalha que coloca cada um de nós num campo ou no outro. Não há sujeito neutro. Somos forçosamente adversários de alguém (FOUCAULT, 2005, p. 58-59-grifos meus).

Ora, esse discurso da luta das raças, a partir do século XVII, com todos os sentidos e objetivos comportava, progressivamente vai se tornando, já no século $\mathrm{XX}$, um discurso que se assemelha mais não a uma luta entre duas raças, e sim a uma luta de uma raça, concebida como "verdadeira e única", contra os indivíduos que aparecem como perigosos no que tange ao tema do "patrimônio biológico". É no contexto dos discursos biológico-racistas, portanto, que aparecerá, no interior das instituições e do corpo social como um todo, um discurso da luta das raças que funcionará "como princípio de eliminação, de segregação e, finalmente, de normalização da sociedade" (FOUCAULT, 2005, p. 73). Com isso, o discurso histórico-político da luta das raças assume uma nova tonalidade, isto é, não se trata mais de defender a sociedade e o conjunto de suas instituições contra os inimigos externos; trata-se, fundamentalmente, não de defender a sociedade contra os inimigos externos, mas de "defender a sociedade contra todos os perigos biológicos dessa outra raça, dessa sub-raça, dessa contra-raça que estamos, sem querer, constituindo. Nesse momento, a temática racista não vai mais parecer ser o instrumento de luta de um grupo social contra o outro, mas vai servir à estratégia global dos conservadorismos sociais" (FOUCAULT, 2005, p. 73). Com efeito, o racismo de Estado funciona como uma forma de racismo de uma sociedade sobre ela mesma e sobre a totalidade de seus próprios elementos. Em última instância, o racismo de Estado, atrelado ao tema da purificação da raça, implicará em todo um amplo processo de normalização do corpo social como um todo.

\section{A CONTRA HiSTÓRIA da LUTA dAS RAÇAS}


Foucault afirma que, até o final do século XIX, antes de assumir a forma de um discurso racista, o discurso da guerra das raças se apresentou como uma espécie de "contra-história". Grosso modo, na ótica de Foucault, a história tradicional e o discurso dos historiadores sempre estiveram associados aos rituais de poder, seja no sentido de oferecer uma justificação do poder soberano, seja no sentido de produzir um fortalecimento desse mesmo poder. Diz Foucault:

Duplo papel: de uma parte, ao narrar a história, a história dos reis, dos poderosos, dos soberanos e de suas vitórias (ou, eventualmente, de suas derrotas provisórias), trata-se de vincular juridicamente os homens ao poder mediante a continuidade da lei, que se faz aparecer no interior desse poder e em seu funcionamento; de vincular, pois, juridicamente os homens à continuidade do poder e mediante a continuidade do poder. De outra parte, trata-se também de fasciná-los pela intensidade, apenas suportável, da glória, de seus exemplos e de suas façanhas. $\mathrm{O}$ jugo da lei e o brilho da glória, essas me parecem ser as duas faces pelas quais o discurso histórico visa a certo efeito de fortalecimento desse poder. A história, como os rituais, como as sagrações, como os funerais, como as cerimônias, como os relatos legendários, é um operador, um intensificador desse poder (FOUCAULT, 2005, p. 76-77).

Já no fim da Idade Média, no decorrer do século XVI e no início do século XVII, vê-se surgir um "novo" discurso, portanto, oposto ao discurso da soberania e da raça; isto é, trata-se de um discurso das raças, do enfrentamento, da luta e da guerra das raças por intermédio das nações e das leis - Foucault caracteriza esse "novo" discurso como sendo um discurso histórico totalmente antitético àquele da história da soberania; além disso, ele se configura numa primeira tentativa de descrever a história que não seja a romana no mundo Ocidental. Para Foucault, o discurso da luta das raças colocará em xeque o binômio povo-monarca ou nação-soberano que a história da soberania evidenciava. A narrativa histórica e a prática dos historiadores sofrerá uma inflexão importante: a narrativa histórica como sendo a história dos grandes, dos vencedores, dos fortes etc., vai ser substituída pelo princípio de que "a história de uns não é a história dos outros", isto é, se verá que a vitória, a lei e o direito, se percebidos desde o outro lado, nada mais são do que o abuso, a injustiça, a violência e a extorsão dos primeiros (vencedores) sobre os outros (vencidos). O novo discurso da luta das raças mostrará, portanto, que a força, a glória e o brilho do poder soberano, tal como narrados pela história tradicional, darão lugar a uma nova explicação da história: o triunfo de uns significará, por outro lado, a submissão de outros (FOUCAULT, 2005, p. 80-81).

Para Foucault, o discurso da guerra das raças assume a conotação mais de um discurso histórico mítico-religioso dos judeus do que propriamente de um discurso com conotação político-legendária como era o dos romanos. Nesse sentido, o que está no cerne do novo discurso da guerra e da luta das raças é demonstrar que o poder, os poderosos, os soberanos, os reis, as leis etc. são o resultado da injustiça e da violência das batalhas e das guerras. Além disso, a contra-história da luta das raças é uma crítica e uma ofensiva contra os poderes instituídos. Isto é, em seu cerne encontra-se a reivindicação de direitos historicamente ignorados. Portanto, contrariamente ao discurso histórico romano, o discurso da luta das raças - um discurso de caráter bíblico - é um discurso que reivindica um direito justo declarando guerra às leis e ao seu caráter opressor, violento e injusto; é um discurso profético e revolucionário cujo objetivo é destruir totalmente a ordem (injusta e violenta) das coisas. Diz Foucault: 
histórico das sociedade indo-europeias, mas a uma percepção e a uma repartição binária da sociedade e dos homens: de um lado uns, do outro lado os outros, os injustos e os justos, os senhores e aqueles que lhes são submissos, os ricos e os pobres, os poderosos e aqueles que só têm seus braços, os invasores das terras e aqueles que tremem diante deles, os déspotas e o povo ameaçador, os homens da lei presente e aqueles da pátria futura. Foi em meados da Idade Média que Petrarca formulou esta questão que acho bastante surpreendente e, em todo caso, fundamental. Ele dizia o seguinte: "Que há, então, na história, que não seja a louvação de Roma?". Eu creio que com essa única pergunta ele caracterizava com uma palavra a história tal como efetivamente ela sempre fora praticada, não somente na sociedade romana, mas nessa sociedade medieval à qual ele próprio, Petrarca, pertencia. Alguns séculos depois de Petrarca, aparecia, nascia no Ocidente uma história que, precisamente, compreendia coisa muito diferente do que a louvação de Roma, uma história em que se tratava, muito pelo contrário, de desmascarar Roma como uma nova Babilônia, e em que se tratava de reivindicar, contra Roma, os direitos perdidos de Jerusalém. Nasciam uma forma totalmente diferente de história, uma função totalmente diferente do discurso histórico. Poderíamos dizer que essa história é o começo do fim da historicidade indoeuropeia, quero dizer, de um certo modo indo-europeu de contar e de perceber a história. No limite, poderíamos dizer que, quando nasce o grande discurso sobre a história da luta das raças, acaba a Antiguidade - e, com Antiguidade, quero dizer essa consciência de continuidade que se tinha, ainda tarde na Idade Média, em relação à Antiguidade (FOUCAULT, 2005, p. 86-87).

A emergência do discurso sobre a guerra das raças estabeleceu, também, uma espécie de ruptura histórico-temporal, ao mesmo tempo, na consciência, na prática e na política da Europa; aos olhos de Foucault, portanto, temos o início de uma modificação importante, no fim da Idade Média, nos séculos XVI e XVII, no que concerne a uma sociedade cuja consciência histórica estava essencialmente centrada numa sociedade de tipo romana, cuja função principal era, por conseguinte, narrar os rituais de soberania e o conjunto de seus mitos de origem (fundação). A sociedade moderna, por sua vez, faz aparecer uma sociedade caracterizada por consciência histórica totalmente diferente: ao invés de centrar-se na soberania e em seus mitos fundadores, preocupa-se com a "revolução, em suas promessas e em suas profecias de libertação futuras" (FOUCAULT, 2005, p. 93). Então, na primeira metade do século XIX, no momento em que o discurso da luta das raças estava assumindo a forma de um discurso revolucionário, em termos de luta de classes (Thiers), houve uma tentativa de requalificação da contra-história da luta das raças, pelo Estado moderno, no sentido biológico e médico da luta de raças. É aqui, segundo Foucault, que se forma o racismo. Diz Foucault:

É assim que, no momento em que se forma uma contra-história de tipo revolucionário, vai-se formar uma outra contra-história, mas que será uma contrahistória na medida em que esmagará, numa perspectiva biológico-médica, a dimensão histórica que estava presente nesse discurso. É assim que vocês veem aparecer algo que é o racismo. Retomando, reciclando a forma, o alvo e a própria função do discurso sobre a luta das raças, mas deturpando-os, esse racismo se caracterizará pelo fato de que o tema da guerra histórica - com suas batalhas, suas invasões, suas pilhagens, suas vitórias e suas derrotas - será substituído pelo tema biológico, pós-evolucionista, da luta pela vida. Não mais batalha no sentido guerreiro, mas luta no sentido biológico: diferenciação das espécies, seleção dos mais forte, manutenção das raças mais bem adaptadas etc. Assim, o tema da sociedade binária, dividida entre duas raças, dois grupos estrangeiros, pela língua, 
pelo direito etc., vai ser substituído pelo de uma sociedade que será, ao contrário, biologicamente monística. [...] Enfim, o tema do Estado, que era necessariamente injusto na contra-história das raças, vai se transformar em tema inverso: o Estado não é o instrumento de uma raça contra a outra, mas é, e deve ser, o protetor da integridade, da superioridade e da pureza da raça. A ideia da pureza da raça, com tudo o que comporta a um só tempo de monístico, de estatal e de biológico, será aquela que vai substituir a ideia da luta das raças (FOUCAULT, 2005, p. 94-95grifos meus).

Foucault mostra, portanto, que é precisamente no momento que a luta das raças assume mais o sentido de uma luta pela pureza da raça que emerge o racismo. Além disso, Foucault demostra que houve, também, toda uma requalificação da lei, do jurídico e da própria noção de raça. Grosso modo, nesse momento, a lei se transforma em norma, o jurídico em biológico e a raça passa a ser entendida não mais no sentido plural das raças: de agora em diante, é no singular que a raça é entendida. Portanto, se o discurso da luta das raças foi um instrumento de luta e de oposição ao discurso histórico-político da soberania de tipo romana, o discurso da raça (em seu sentido singular, como descrito acima) foi o instrumento utilizado pelo Estado moderno para conservar sua soberania e o brilho de seu poder; além disso, os procedimentos de justificação e de legitimação do poder soberano (isto é, os "procedimentos mágicojurídicos") foram progressivamente substituídos pelo Estado moderno por "técnicas médico-normalizadoras" (FOUCAULT, 2005, p. 95). É nesse contexto que o Estado moderno lançou mão de todo um discurso que enfatiza, contra a promessa de libertação característica do discurso revolucionário, a pureza e a proteção da raça.

No século XX, o nazismo alemão e o socialismo soviético se configuraram nas duas experiências históricas extremas de inserção do racismo no interior do aparelho estatal. Na próxima seção, eu me ocupo em apresentar as transformações principais das técnicas e dos procedimentos de poder na modernidade. Trato, especialmente, do tema da biopolítica e, em seguida, descrevo a forma como o nazismo alemão e o socialismo soviético inseriram profundamente no seio da sociedade o tema do racismo, da pureza da raça e da luta das raças.

\section{O RACISMO DE ESTADO}

Volto-me agora ao problema do racismo de Estado. Na última aula (17 de março de 1976), Foucault articula duas ideias essenciais de suas reflexões no curso Em Defesa da Sociedade: o problema político do poder e o tema da histórico da guerra das raças. Assim, Foucault faz uma genealogia do racismo tomando como pano de fundo o discurso histórico da luta das raças, nos séculos XVII e XVIII, e analisa as transformações do racismo nos séculos XIX e XX, tomando como referências as experiências totalitárias que marcaram profundamente a modernidade, o nazismo alemão e o socialismo soviético.

A genealogia do racismo é feita em contraposição à teoria clássica da soberania. Para Foucault, na teoria clássica da soberania, o "direito de vida e de morte" era um dos atributos essenciais do poder soberano. É interessante que nos atentemos para o significado que Foucault dá a esse "direito de vida e de morte": ter o "direito de vida e de morte" significa, fundamentalmente, no âmbito do poder soberano, ter o direito de "fazer morrer ou de deixar viver". Notem que, ao assumir o direito de vida e de morte do súdito, o soberano faz com que a vida e a morte saiam do âmbito dos fenômenos 
naturais ou como condição original do homem (o traço finito da vida humana), e passem a fazer parte do campo político. O paradoxo essencial da abordagem soberana consiste no fato de que o súdito, do ponto de vista das relações de poder, "não é, de pleno direito, nem vivo nem morto". [...] Ele é, do ponto de vista da vida e da morte, neutro, e é simplesmente por causa do soberano que o súdito tem o direito de estar vivo ou tem o direito, eventualmente, de estar morto. Em todo caso, a vida e a morte dos súditos só se tornam direitos pelo efeito da vontade soberana" (FOUCAULT, 2005, p. 286). Portanto, há um desequilíbrio profundo de forças na forma como o soberano exerce seu direito de vida e de morte. O paradoxo pode, então, ser explicado da seguinte forma: "o poder soberano sobre a vida só se exerce a partir do momento em que o soberano pode matar. [...] o direito de matar é que detém efetivamente em si a própria essência desse direito de vida e de morte: é porque o soberano pode matar que ele exerce seu poder sobre a vida. É essencialmente um direito de espada" (FOUCAULT, 2005, p. 286-287).

Ao demonstrar o paradoxo soberano expresso no "direito de fazer morrer ou de deixar viver", Foucault pode situar uma das principais transformações do direito político do século XIX, a saber, o "direito de fazer viver e de deixar morrer" (FOUCAULT, 2005, p. 287). Ora, essa transformação está diretamente associada àquilo que Foucault denominou de "estatização do biológico", isto é, a emergência e o desenvolvimento de toda uma tecnologia de poder que se aplica não mais aos indivíduos e seus corpos - a anátomo-política do corpo implantada nos séculos XVII e XVIII-, mas a vida e ao conjunto dos processos biológicos da espécie humana (natalidade, morbidade, incapacidades biológicas, as doenças etc.). A essa nova tecnologia de poder, Foucault chamou de "biopolítica"2.

Com efeito, essa nova tecnologia de poder está associada ao aparecimento da população como problema científico e político, isto é, como problema científicomédico-biológico e como problema de poder. A biopolítica, nesse sentido, vai se ocupar fundamentalmente com um conjunto de fenômenos de massa, e se utilizará de dispositivos normalizadores (previsões, estatísticas, medições etc.), cujo objetivo é a gestão reguladora desses mesmos processos populacionais. Diz Foucault:

[...] aquém, portanto, do grande poder absoluto, dramático, sombrio que era o poder de soberania, e que consistia em poder fazer morrer, eis que aparece agora, com essa tecnologia do biopoder, com essa tecnologia de poder sobre a 'população' enquanto tal, sobre o homem enquanto ser vivo, um poder contínuo, científico, que é o poder de 'fazer viver'. A soberania fazia morrer e deixava viver. E eis que agora aparece um poder que eu chamaria de regulamentação e que consiste, ao contrário, em fazer viver e em deixar morrer (FOUCAULT, 2005, p. 294).

Então, na perspectiva de Foucault, se no antigo poder de soberania havia uma espécie de "ritualização pública da morte", destinada a reforçar e conceder brilho e louvor ao próprio poder soberano, a partir do final do século XVII vemos ocorrer um certo apagamento desse ritual, isto é, ele se torna algo privado e vergonhoso, que é preciso esconder aos olhos do público. Foucault argumenta que isso se deve não a uma modificação dos dispositivos e mecanismos de repressão: tal modificação deve ser situada no contexto das transformações das próprias tecnologias de poder. A biopolítica se apresenta como esse novo poder, que fez com que se abandonasse o velho direito soberano de fazer morrer, que intervém direta e principalmente para fazer viver e na própria maneira de viver da população, isto é, sua capacidade de ação se concentra mais 
em aumentar a possibilidade da vida, de controlar tanto suas deficiências quanto suas eventualidades e acidentes (FOUCAULT, 2005, p. 294-302). É nesse contexto, também, que a medicina vai se apresentar como uma técnica política de intervenção e de controle e gestão da população, ou seja, ela se apresenta como uma técnica de poder-saber que se aplica, ao mesmo tempo, ao corpo individual e a população: portanto, ela terá um caráter, ao mesmo tempo, disciplinar e regulamentador ${ }^{3}$. Foucault designou como "norma" esse elemento que articula o caráter disciplinar e regulamentador do biopoder. Diz ele:

A norma pode tanto se aplicar a um corpo que se quer disciplinar quanto a uma população que se quer regulamentar. A sociedade de normalização não é, pois, nessas condições, uma espécie de sociedade disciplinar generalizada cujas instituições disciplinares teriam se alastrado e finalmente recoberto todo o espaço - essa não é, acho eu, senão uma primeira interpretação, e insuficiente, de ideia de sociedade de normalização. A sociedade de normalização é uma sociedade em que se cruzam, conforme uma articulação ortogonal, a norma da disciplina e a norma da regulamentação. Dizer que o poder, no século XIX, incumbiu-se da vida, dizer pelo menos que o poder, no século XIX, incumbiu-se da vida, é dizer que ele conseguiu cobrir toda a superfície que se estende do orgânico ao biológico, do corpo à população, mediante esse jogo duplo das tecnologias de disciplina, de uma parte, e das tecnologias de regulamentação, de outra (FOUCAULT, 2005, p. 302).

A pergunta central é: como os estados modernos podem exercer o poder/sua função de morte no contexto de um sistema político centrado no - e caracterizado pelo biopoder? É nesse contexto que emerge o racismo. Em outras palavras, a introdução do racismo nos mecanismos de poder estatal só foi possível graças ao aparecimento do biopoder e da biopolítica como tecnologia principal de controle e de gestão da população nas sociedades modernas. O racismo, portanto, foi o meio adequado encontrado para que o Estado moderno pudesse realizar, no domínio da biopolítica, uma cisão, um corte, uma separação entre o que "deve viver e o que deve morrer", ou seja, "no contínuo biológico da espécie humana, o aparecimento das raças, a distinção das raças, a hierarquia das raças, a qualificação de certas raças como boas e de outras, ao contrário, como inferiores, tudo isso vai ser uma maneira de fragmentar esse campo do biológico de que o poder se incumbiu; uma maneira de defasar, no interior da população, uns grupos em relação aos outros" (FOUCAULT, 2005, p. 304). A primeira função do racismo moderno consiste em estabelecer uma série de cesuras, de fragmentações, em última instância, em subdividir a espécie humana em raças.

Além desta, o racismo desempenha uma segunda função no âmbito dos estados modernos: trata-se de uma "função positiva", traduzida no fato de que "quanto mais você matar, mais você fará morrer"; "quanto mais você deixar morrer, mais, por isso mesmo, você viverá" (FOUCAULT, 2005, p.305). Portanto, o racismo insere nas tecnologias de poder modernas um tipo de relação não mais no sentido militar e guerreiro de enfrentamento, mas no sentido biológico; em outras palavras, da eliminação da raça ruim, do indivíduo degenerado, do inferior, do anormal etc. resultará que a espécie possa viver mais, possa ser mais forte, possa prosperar, isto é, vai permitir que a vida humana possa se tornar mais sadia: "a morte do outro não é apenas a minha vida, na medida em que seria minha segurança pessoal; a morte do outro [...] é que vai deixar a vida em geral mais sadia; mais sadia e mais pura" (FOUCAULT, 2005, p. 305). Vejam que, nesse momento, o inimigo a ser combatido e vencido não é mais o 
inimigo/adversário entendido no sentido político do termo, e sim os perigos biológicos externos e internos que ameaçam a vida da população. Portanto, é o argumento do fortalecimento e da proteção da espécie e da raça humana que serviu de justificativa última para se exercer o poder de morte em uma sociedade de normalização: "a função assassina do Estado só pode ser assegurada desde que o Estado funcione no modo do biopoder, pelo racismo"4 (FOUCAULT, 2005, p. 306).

Para Foucault, no século XIX, vemos aparecer um vínculo profundo entre a teoria biológica e o discurso e a prática do poder. A teoria evolucionista (e, no seu interior, os temas da hierarquia da espécie, a luta pela vida entre as espécies, a eliminação dos menos adaptados etc.) se configurou, no século XIX, na forma como se pensou uma série de relações, que vai desde a colonização ${ }^{5}$ até a problematização da história das sociedades com suas diferentes classes, passando pelo problema das guerras, da criminalidade e da punição, o isolamento do louco e do doente mental.

Com efeito, toda vez que o Estado quis exercer o seu direito de matar, foi no evolucionismo, mediatizado pelo tema do racismo, que ele encontrou sua base de sustentação e justificativa. Nesse sentido, ao analisar o problema do racismo de Estado, Foucault faz notar que, na segunda metade do século XIX, o racismo se estrutura, em sociedades marcadas pelo biopoder, em torno do princípio de que a morte do outro entendido tanto como adversário externo quanto como adversário interno - representa, ao mesmo tempo, o fortalecimento biológico da própria pessoa (considerada como membro de uma raça) ou de uma população (considerada como pluralidade unitária e viva) (FOUCAULT, 2005, p. 308). Além disso, Foucault faz notar que o racismo, nesse período, era algo totalmente diferente do desprezo ou ódio de uma raça pela outra; o racismo era, também, algo totalmente diferente de uma "operação ideológica" do Estado ou de uma classe. Diz Foucault:

[...] A especificidade do racismo moderno, o que faz sua especificidade, não está
ligado a mentalidades, a ideologias, a mentiras do poder. Está ligado à técnica do
poder, à tecnologia do poder. Está ligado a isto que nos coloca, longe da guerra
das raças e dessa inteligibilidade da história, num mecanismo que permite ao
biopoder exercer-se. Portanto, o racismo está ligado ao funcionamento de um
Estado que é obrigado a utilizar a raça, a eliminação das raças e a purificação da
raça para exercer seu poder soberano. A justaposição, ou melhor, o
funcionamento, através do biopoder, do velho poder soberano do direito de morte
implica o funcionamento, a introdução e a ativação do racismo. E é aí, creio eu,
que efetivamente ele se enraíza (FOUCAULT, 2005, p. 309).

Duas experiências totalitárias podem ser citadas como exemplo do caráter racista do Estado moderno: o nazismo alemão e o socialismo soviético. O nazismo utilizou ao máximo os mecanismos de poder surgidos a partir do século XVIII (os mecanismos disciplinares e os mecanismos médico-biológico-normalizadores) e os fez sustentar toda a retórica do regime, estritamente ligada ao tema do biológico, da hereditariedade, da procriação etc. Além disso, o nazismo fez com que o poder de matar e o poder soberano se prolongassem à totalidade do corpo social, isto é, o tema da guerra é reinterpretado como a "fase última e decisiva de todos os processos políticos", ou seja, não é só a destruição e a eliminação das outras raças o objetivo último do regime nazista; existe uma outra face do regime, a saber, a exposição da própria população e da própria raça alemã ao risco da morte e ao perigo da destruição total. Portanto, o Estado nazista coroa dois elementos essenciais surgidos na modernidade: de um lado, ele generalizou os mecanismos do biopoder ao conjunto do corpo social; em seguida, ele utilizou 
amplamente o direito soberano de matar ou de expor uma população à destruição total. Diz Foucault:

Os dois mecanismos, o clássico, arcaico, que dava ao Estado o direito de vida e de morte sobre seus cidadãos, e o novo mecanismo organizado em torno da disciplina, da regulamentação, em suma, o novo mecanismo do biopoder, vêm, exatamente, a coincidir. De sorte que se pode dizer isto: o Estado nazista tornou absolutamente coextensivos o campo de uma vida que ele organiza, protege, garante, cultiva biologicamente, e, ao mesmo tempo, o direito soberano de matar quem quer que seja - não só os outros, mas os seus próprios. Houve, entre os nazistas, uma coincidência de um biopoder generalizado com uma ditadura a um só tempo absoluta e retransmitida através de todo o corpo social pela formidável junção do direito de matar e da exposição à morte. Temos um Estado absolutamente racista, um Estado absolutamente assassino e um estado absolutamente suicida. [...] Solução final para as outras raças, suicídio absoluto da raça alemã (FOUCAULT, 2005, p. 311-12).

O racismo biológico-evolucionista - e não étnico - também caracterizou o funcionamento e o exercício do poder no interior do Estado socialista soviético (especialmente contra os doentes mentais, os criminosos, os adversários políticos etc.). Foucault percebe duas diferenças essenciais na forma como o racismo funcionou no cerne do Estado e do projeto socialistas: no plano econômico, sobretudo quando os socialistas procuram efetivar transformações profundas nas condições econômicas (passagem de um Estado capitalista para um Estado socialista), não houve necessidade de racismo; no plano das lutas contra os inimigos e da eliminação dos adversários políticos, bem como no âmbito do enfrentamento físico contra o adversário de classe no interior do Estado capitalista, o socialismo soviético insistiu e fez uso do racismo como arma biopolítica para justificar a morte do inimigo. Portanto, contrariamente ao regime nazista, que levou ao extremo o poder de morte, inclusive expondo a própria população alemã a eliminação total, o socialismo soviético, no momento do enfrentamento e de eliminação do inimigo de classe, se serviu do racismo biopolítico como mecanismo de poder.

\section{CONCLUSÃo}

$\mathrm{O}$ artigo investiga o tema do racismo de Estado. Tomando como referência o curso Em Defesa da Sociedade, ministrado por Michel Foucault no Collège de France nos anos de 1975-1976, nosso objetivo foi demonstrar a emergência de um racismo de Estado no âmbito das sociedades modernas. Foucault demonstrou como o tema da luta das raças, no século XVII, progressivamente se modificou e assumiu a forma, no século $\mathrm{XX}$, de um discurso não mais no sentido de uma luta entre duas raças, mas sim no sentido de uma luta de uma raça ("verdadeira e única") contra os indivíduos considerados perigosos ao "patrimônio biológico" da espécie humana. Portanto, no contexto dos discursos biológico-racistas modernos, aparecerá, no interior das instituições e do corpo social como um todo, um discurso da luta das raças que funcionará como um princípio de eliminação, de segregação e, finalmente, de normalização da sociedade. Em última instância, o discurso histórico-político da luta das raças não se preocupará mais em defender a sociedade dos perigos/inimigos externos; o alvo agora são os inimigos internos, isto é, aqueles que representam um perigo biológico à espécie humana. $\mathrm{O}$ racismo de Estado, associado à sua retórica da 
purificação e da proteção da raça, levará ao limite o processo de normalização social. No cerne do caráter biopolítico, o racismo se configurou no meio apropriado para que o Estado pudesse estabelecer uma cisão entre aquilo que "deve viver" e aquilo que "deve morrer”. O nazismo alemão e o socialismo soviético se apresentam como as duas experiências histórico-totalitárias que levaram ao extremo o caráter racista do Estado moderno, especialmente pela utilização de mecanismos disciplinares e médicobiológico-normalizadores -nazismo alemão - e, também, um complexo biológicoevolucionista (e não étnico) - socialismo soviético.

\section{REFERENCIAS}

ADVERSE, Helton. "Foucault, Maquiavel e a crítica da razão política moderna". Revista Filosófica de Coimbra, n 46, 2014, p. 293-316.

CASTRO-GÓMEZ, Santiago. Crítica de la Razón Latinoamericana. Bogotá: Pontiicia Universidad Javeriana/Instituto Pensar, 2011.

COOPER, Melinda. Life as Surplus: Biotecnology \& Capitalism in the Neoliberal Era. Washington: University of Washington Press, 2008.

ESPOSITO, Roberto. Bios: Biopolitics and Philosophy. Minneapolis: University of Minnesota Press, 2008.

FOUCAULT, Michel. Vigiar e Punir: História da Violência nas Prisões. Petrópolis: Editora Vozes, 1975.

FOUCAULT, Michel. História da Sexualidade I: A Vontade de Saber. Rio de Janeiro: Edições Graal, 1988.

FOUCAULT, Michel. Em defesa da sociedade. Curso no Collège de France (1975-1976). São Paulo: Martins Fontes, 2005.

FOUCAULT, Michel. Nascimento da Biopolítica. Curso dado no Collège de France (1977-1978). São Paulo: Martins Fontes, 2008.

LEMKE, Thomas. Foucault, Governamentalidade e Crítica. São Paulo: Editora Autonomia Literária, 2017.

LEMKE, Thomas. Biopolítica: Críticas, Debates e Perspectivas. São Paulo: Editora Politéia, 2018.

MBEMBE, Achille. Crítica da Razão Negra. Lisboa: Antígona, 2014.

RAJAN, Kaushik Sunder. Biocapital: The Constitution of Postgenomic Life. Durham and London: Duke University Press, 2006.

ROSE, Nikolas. The Politics of Life Itself: Biomedicine, Power, and Subjectivity in the TwentyFirst Century. New Jersey: Princton University Press, 2007.

\section{Notas}

1 Para Foucault, "apreender a instância material da sujeição enquanto constituição dos súditos seria, se vocês quiserem, exatamente o contrário do que fez Hobbes no Leviatã, e todos os juristas, quando o procedimento deles é saber como, a partir da multiplicidade dos indivíduos e das vontades, pode se formar uma vontade única ou ainda um corpo únicos, mas animados por uma alma que seria a soberania. [...] Lembrem-se do esquema do Leviatã: nesse esquema, o Leviatã, enquanto homem fabricado, não é mais do que a coagulação de um certo número de individualidades separadas, que se encontram reunidas por certo número de elementos constitutivos do Estado. Mas, no coração, ou melhor, na cabeça do Estado, existe alguma coisa que o constitui como tal, e essa alguma coisa é a soberania, da qual Hobbes diz que é precisamente a alma do Leviatã" (FOUCAULT, 2005, p. 33-34).

2 Para uma compreensão mais aprofundada desse termo, sugiro a leitura de História da Sexualidade I: A Vontade de Saber (1988) e do curso Nascimento da Biopolítica (1977- 
1978). Além desses textos, sugiro a leitura de intérpretes e comentadores, tais como: LEMKE, Thomas, Biopolítica: Críticas_Debates_Perspectivas (2018) e LEMKE, Thomas. Foucault, Governamentalidade e- Crítica (2017); ESPOSITO, Roberto. Bios: Biopolitics and Philosophy (2008); RAJAN, Kaushik Sunder. Biocapital: The Constitution of Postgenomic Life (2006); COOPER, Melinda. Life as Surplus (2008).

803 Sobre o tema da medicina como técnica biopolítica, ver, sobretudo, ROSE, Nikolas. The Politics of Life Itself: Biomedicine, Power, and Subjectivity in the Twenty-First Century (2007).

4 Por "tirar a vida", Foucault entende tanto o assassínio direto (o fato de tirar a vida efetivamente) quanto o assassínio indireto (a exposição de um indivíduo ou de uma multiplicidade de indivíduos à morte, a morte política, a expulsão, a rejeição etc.) (FOUCAULT, 2005, p. 306).

5 Sobre a relação entre racismo e colonialismo, ver, especialmente, MBEMBE, Achille. Crítica da Razão Negra (2014) e CASTRO-GÓMEZ, Santiago. Crítica de la Razón Latinoamericana (2011). 